\title{
Corrosion resistance and cytocompatibility of Ti-20Zr-10Nb-4Ta alloy surface modified by a focused fiber laser
}

\author{
Xianda Xue ${ }^{1}$, Chengpeng $\mathrm{Ma}^{2}$, Hongjuan $\mathrm{An}^{1}$, Yan $\mathrm{Li}^{1,3^{*}}$ and Yingchun Guan ${ }^{2,4,5^{*}}$
}

\begin{abstract}
The corrosion resistance and cytocompatibility of Ti-20Zr-10Nb-4Ta (TZNT) alloy modified by surface laser treatment were investigated. The scanning electron microscopy (SEM) measurements indicated that laser treatment on TZNT alloy generated groove morphologies with the width of $\sim 40 \mu \mathrm{m}$ and the depth of $\sim 10 \mu \mathrm{m}$ on the surface. The water contact angles along the groove direction decreased by $51 \%$ compared with that of the untreated alloy. The laser treatment promoted the oxidation of metallic $\mathrm{Ti}, \mathrm{Zr}$ and $\mathrm{Nb}$ and produced more stable oxides on surface. The corrosion potential increased by $50 \%$ and corrosion current density decreased by $\mathbf{7 2} \%$ compared with that of the untreated alloy in the anodic polarization test for the alloy in Hank's solution at $37^{\circ} \mathrm{C}$. This indicated the improvement of the corrosion resistance by laser treatment. The cytotoxicity testing results showed that the laser-treated TZNT alloy performed similar MC3T3-E1 cell viability compared with the untreated alloy. The cells displayed oriented growth along the groove direction due to the increased hydrophilicity. This novel material may be a new candidate in orthopedics and dentistry implantations fields.
\end{abstract}

Keywords: laser, Ti-20Zr-10Nb-4Ta, corrosion resistance, cytocompatibility

\section{INTRODUCTION}

Due to the high strength to weight ratio, good corrosion resistance, and low density, commercially pure titanium (CP-Ti) and $\mathrm{Ti}-6 \mathrm{Al}-4 \mathrm{~V}$ alloys have been widely used in biomedical fields such as orthopedics and dental implantations $[1,2]$. However, the disadvantages of CP-Ti and $\mathrm{Ti}-6 \mathrm{Al}-4 \mathrm{~V}$ in clinical applications, e.g., very high Young's modulus, and toxic effects of $\mathrm{V}$ and $\mathrm{Al}$ elements, triggered the development of new bio-safe $\mathrm{Ti}$ alloys exhibiting low Young's modulus comparable to human bones $[3,4,5]$. Therefore, many $\mathrm{Ti}$ alloys made of nontoxic elements, e.g., Ti-Zr [6], Ti-Nb [7], Ti-13Nb-13Zr [8], Ti-35Nb-5Ta-7Zr [9], Ti-29Nb-13Ta-4.6Zr [10], and Ti-38.3Ta-22Zr-8.1Nb [11] alloys have been extensively investigated. These alloys exhibited low Young's modulus, good mechanical properties and excellent biocompatibility, showing the promise as new candidates in biomedical applications. Moreover, some of the recently developed $\mathrm{Ti}$ alloys such as $\mathrm{Ti}-19 \mathrm{Zr}-10 \mathrm{Nb}-1 \mathrm{Fe}[12,13]$ and $\mathrm{Ti}-20 \mathrm{Zr}-10 \mathrm{Nb}-4 \mathrm{Ta}$ [14] behaved good superelasticity and shape memory effects, and thus may challenge the Nitinol shape memory alloy in future clinical applications.

The laser surface treatment has been used to improve the mechanical properties, corrosion resistance and biocompatibility of Ti alloys $[15,16]$. On the one hand, a homogeneous microstructure and stable oxidation layer can be produced on the surface of the alloy owing to rapid re-solidification [17]. On the other hand, the heat energy localized at the surface level, leaving the bulk properties unaffected [18]. Lawrence et al. [19] indicated that the adhesiveness and proliferation of osteoblast cells can be enhanced when Ti-6Al-4V alloy was treated by a pulsed $\mathrm{Nd}$ : YAG laser, owing to the increased surface roughness and improved wettability. Chen et al. [20] reported that laser-treated microgrooves on Ti-6Al-4V alloy promoted

${ }^{1}$ School of Materials Science and Engineering, Beihang University, Beijing 100191, China

${ }^{2}$ School of Mechanical Engineering and Automation, Beihang University, Beijing 100191, China

${ }^{3}$ Beijing Advanced Innovation Centre for Biomedical Engineering, Beihang University, Beijing 100191, China

${ }^{4}$ National Engineering Laboratory of Additive Manufacturing for Large Metallic Components, Beihang University, Beijing 100191, China

${ }^{5}$ International Research Institute for Multidisciplinary Science, Beihang University, Beijing 100191, China

* Corresponding authors (emails: liyan@buaa.edu.cn (Li Y); guanyingchun@buaa.edu.cn (Guan Y)) 
cell adhesion with enhanced interactions between the focal adhesions and the extra-cellular matrix (ECM) proteins. Ulerich et al. [21] modified the Ti-6Al-4V surfaces by direct-write laser machining to form linear grooves and the grooves exhibit basic features of contact guidance for cell growth.

In our previous work, the $\mathrm{Ti}-20 \mathrm{Zr}-10 \mathrm{Nb}-4 \mathrm{Ta}$ alloy was found exhibiting good mechanical properties as well as shape memory effect [14]. In the present work, a focused laser surface treatment has been performed on the Ti$20 \mathrm{Zr}-10 \mathrm{Nb}-4 \mathrm{Ta}$. The effects of laser surface treatment on the corrosion resistance and cytocompatibility were investigated.

\section{MATERIALS AND METHODS}

\section{Materials}

The Ti-20Zr-10Nb-4Ta (at.\%, TZNT) alloy was prepared using high-purity (>99.9 wt.\%) raw materials. The ingots (approximately $1.5 \mathrm{~kg}$ in weight) were re-melted five times for homogeneity via the non-consumable arcmelting method under Ar protection. The as-melted ingots were homogenized at $1237 \mathrm{~K}$ for $6 \mathrm{~h}$ in a vacuum of $10^{-3} \mathrm{~Pa}$, cut into $4 \mathrm{~mm}$ thick pieces, and then cold rolled into sheets with $75 \%$ reduction in thickness. Next, alloy sheets were annealed at $873 \mathrm{~K}$ in vacuum for $30 \mathrm{~min}$ and quenched in water.

The sheets were cut into $11 \mathrm{~mm} \times 11 \mathrm{~mm}$ for experimentation. Before the laser ablation, the sample surface was ground by a series of sandpapers from 240 to 1500 grit and electropolished to a mirror. Then the samples were cleaned ultrasonically in methanol for $10 \mathrm{~min}$, rinsed in distilled water for another $10 \mathrm{~min}$, and dried thoroughly in cold air stream.

\section{Laser ablation}

The laser surface ablation process was performed using a pulsed wave $15 \mathrm{~W}$ fibre laser (PicoYL-15-0.1). The wavelength of the laser is $1064 \mathrm{~nm}$, and the spot size is $35 \mu \mathrm{m}$. After cleaned with methanol and dried in air, the samples were irradiated with the fibre laser using the following processing parameters: laser power: $11.4 \mathrm{~W}$, workpiece scanning speed: $700 \mathrm{~mm} \mathrm{~s}^{-1}$, frequency: 100 $\mathrm{kHz}$, shielding gas type: high purity argon. The Ar gas was delivered to the laser-irradiated area via side gas jets.

\section{Surface topography and chemical composition}

Images of the laser-treated TZNT surfaces were obtained with a scanning electron microscope. The surface profiles were determined using a white light interferometer.
Changes in the chemical states and compositions of the surfaces in the depth direction were analyzed by X-ray photoelectron spectroscopy (XPS), using monochromatic $\mathrm{Al} \mathrm{Ka}$ radiation. The spot size was $500 \mu \mathrm{m}$ and the pass energy was set to $100.0 \mathrm{eV}$ and $30.0 \mathrm{eV}$ for wide spectrum and narrow spectrum scan analysis, respectively. The XPS measurements were measured at the surface of samples without any sputtering.

\section{Contact angle and corrosion tests}

To investigate the wetting properties of surface treated by laser, contact angle measurements were conducted for the laser treated and untreated samples using distilled water within two hours after sample processing. Electrochemical tests were conducted to evaluate the corrosion resistance ability of the untreated and laser treated samples in Hank's solution at a $\mathrm{pH}$ of 7.4. The composition of the Hank's solution included $8.00 \mathrm{~g} \mathrm{~L}^{-1} \mathrm{NaCl}, 0.14 \mathrm{~g} \mathrm{~L}^{-1}$ $\mathrm{CaCl}, 0.40 \mathrm{~g} \mathrm{~L}^{-1} \mathrm{KCl}, 0.10 \mathrm{~g} \mathrm{~L}^{-1} \mathrm{MgCl}_{2} \cdot 6 \mathrm{H}_{2} \mathrm{O}, 0.10 \mathrm{~g} \mathrm{~L}^{-1}$ $\mathrm{MgSO}_{4} \cdot 7 \mathrm{H}_{2} \mathrm{O}, 0.35 \mathrm{~g} \mathrm{~L}^{-1} \mathrm{NaHCO}_{3}, 0.12 \mathrm{~g} \mathrm{~L}^{-1} \mathrm{Na}_{2} \mathrm{HPO}_{4}$. $12 \mathrm{H}_{2} \mathrm{O}, 0.06 \mathrm{~g} \mathrm{~L}^{-1} \mathrm{KH}_{2} \mathrm{PO}_{4}$ and $1.00 \mathrm{~g} \mathrm{~L}^{-1}$ Glucose. Potentio-dynamic polarization tests were carried out using a standard three-electrode system at the temperature of 37 $\pm 0.5^{\circ} \mathrm{C}$ and scan rate of $1 \mathrm{mV} \mathrm{s}^{-1}$, which had a saturated calomel electrode as the reference electrode and a carbon electrode as the counter electrode. The test potential ranged below the open circuit potential of $300 \mathrm{mV}$ to above that of $300 \mathrm{mV}$, and scanned from low potential to high potential. Exposed area of each sample was $1.21 \mathrm{~cm}^{2}$. Polarization measurements started after the samples were immersed in the Hank's solution for 20 min under opencircuit conditions. Beyond that, the open circuit potential curves were measured for $12 \mathrm{~h}$ to obtain stable datum.

\section{Evaluation of cellular response}

MC3T3-E1 cells were cultured in a-modified minimum essential medium ( $\alpha$-MEM) containing $10 \%$ fetal bovine serum (FBS) and 1\% of antibiotic-antimycotic solution at $37^{\circ} \mathrm{C}$ under a humidified atmosphere of $5 \% \mathrm{CO}_{2}$. The TZNT plates were sterilized with the ultraviolet lamp. Each sterilized TZNT plate was placed in a single well of a 12-well polystyrene cell-culture plate. The MC3T3-E1 cells were seeded within each well at a concentration of 1 $\times 10^{4}$ cells $\mathrm{mL}^{-1}$ and then incubated for 12,24 or $72 \mathrm{~h}$. Morphological analysis of the cells was then performed using SEM. To prepare specimens for SEM analysis, the cells were washed three times in PBS ( 5 min each time), fixed with $2.5 \%$ glutaraldehyde under the condition of avoiding light for $1 \mathrm{~h}$ and rinsed in PBS again. Then the cells were dehydrated in sequential concentrations of 

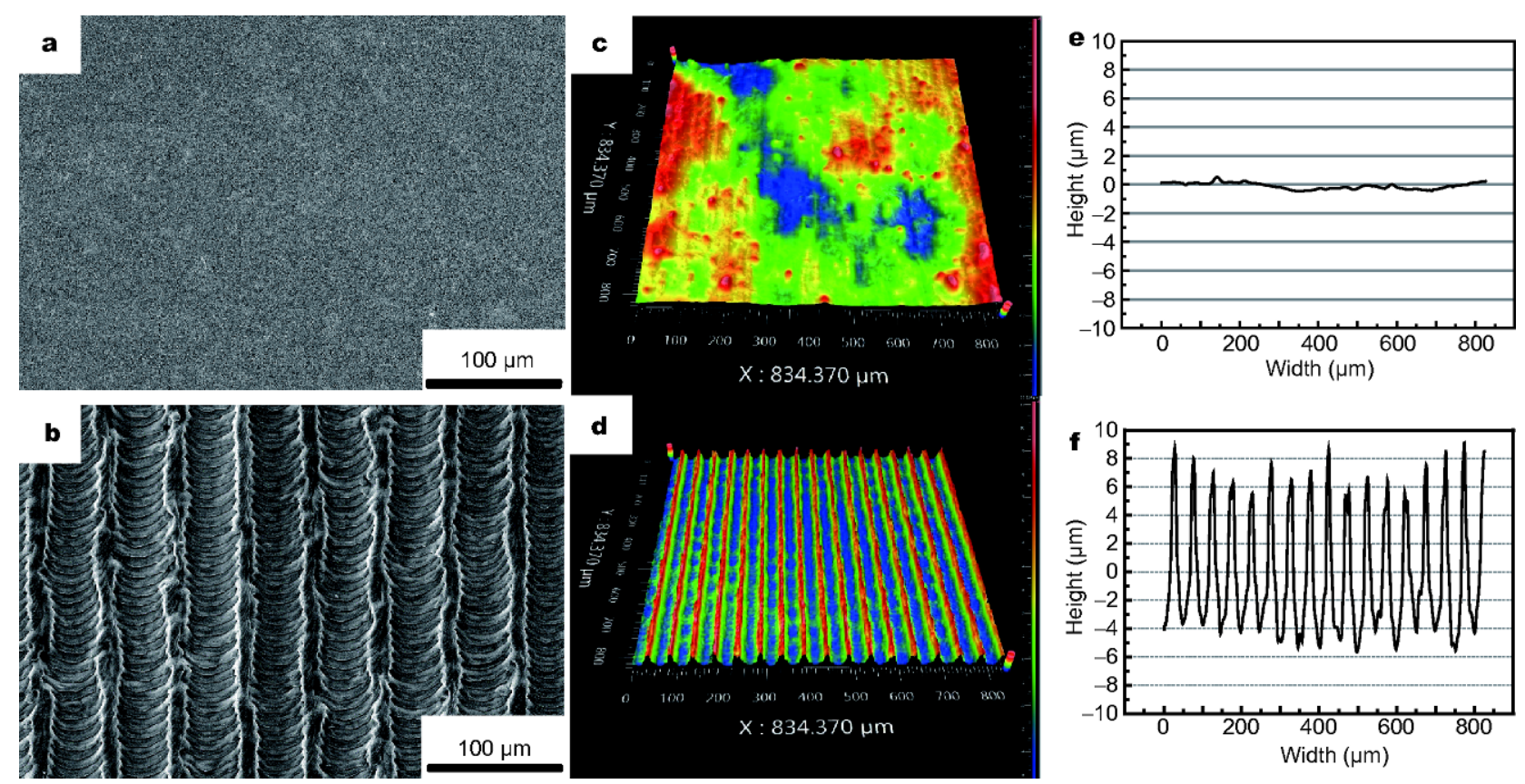

Figure 1 The surface images obtained by SEM: (a) untreated TZNT, (b) laser-treated TZNT surface. 3D surface profiles by optical measurement system: (c) untreated TZNT, (d) laser-treated TZNT. Surface undulation in a line by optical measurement system: (e) untreated TZNT, (f) lasertreated TZNT.

ethanol of $30 \%, 50 \%, 70 \%, 90 \%$ and $100 \%$ (15 min each concentration). The hexamethyl disilylamine was added for $15 \mathrm{~min}$ and then dried in air. After culturing, MTT assay was used to evaluate cell proliferation. The absorbance was measured at a wavelength of $492 \mathrm{~nm}$ on the enzyme-link meter.

\section{Statistical analysis}

All the results are presented as the means \pm standard error of the mean. The data were statistically analyzed using the software program SPSS. One-way ANOVA with Duncan's multiple range test was used to examine differences between the groups. Values of $p<0.05$ were considered significant unless stated otherwise. Data from all experiments are representative from one of at least three repeated experiments.

\section{RESULTS AND DISCUSSION}

\section{Surface characteristics}

Fig. 1 shows the surface topography images of the untreated and laser-treated TZNT samples obtained by SEM and optical measurement system. It is seen in Fig. 1a that the untreated sample is smooth on the surface. However, the surface of the laser-treated sample is covered by rougher groove morphologies (Fig. 1b). It is noted that uniform ripples are observed at the bottom of the grooves. The width of the groove is about $40 \mu \mathrm{m}$, which is slightly larger than the diameter of the laser beam, $35 \mu \mathrm{m}$. The spacing distance of grooves is about $50 \mu \mathrm{m}$, which is almost the same as the distance of laser beam. The 3D surface profile of the untreated sample displays a roughness average $(\mathrm{Ra})$ value of $0.202 \mu \mathrm{m}$ as shown in Fig. 1c. A much higher Ra value of $4.175 \mu \mathrm{m}$ was measured by the 3D surface profile of the laser treated TZNT in Fig. 1d, and corresponding depth of grooves is about $10 \mu \mathrm{m}$ as shown in Fig. 1f. It is known that the microgrooves with stripes are typical topographic features of laser-ablated samples. Mukherjee et al. [22] found that the laser ablation induced micro-grooves and ripples on the laser treated Ti-6Al-4V were dependent on the laser scanning parameters and, moreover, influenced the cellular activities and enhanced the biocompatibility.

\section{Surface wettability}

Fig. 2 shows the water contact angles of the laser-treated and untreated TZNT surfaces. It is seen that all the contact angles of the samples remain below $40^{\circ}$. The average water contact angle of untreated TZNT is isotropic and determined as $36.9^{\circ}$. In contrast, the laser treated TZNT exhibits obviously anisotropic contact angle. For the $\mathrm{P}$ direction, the average water contact angle is 


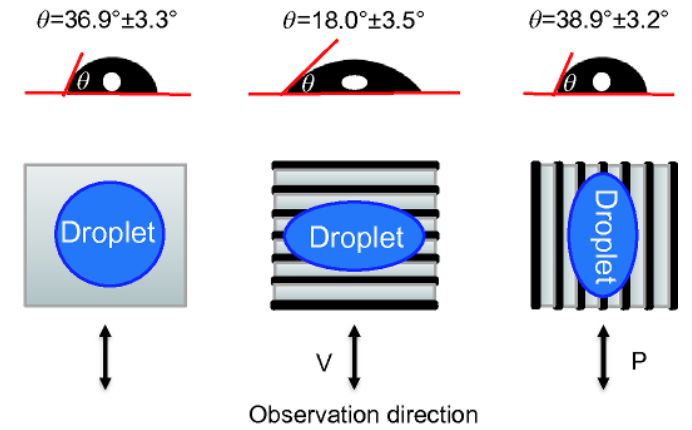

Figure 2 The water contact angles of the laser-treated and untreated TZNT surfaces.

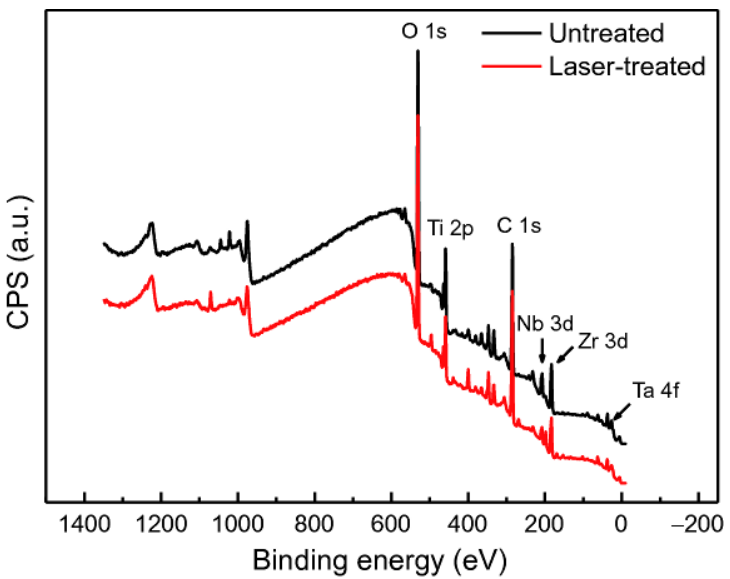

Figure 3 The XPS full spectra of untreated and laser-treated TZNT surface.

$38.9^{\circ}$ which is close to that of the untreated samples. For the $\mathrm{V}$ direction, the average water contact angle is $18.0^{\circ}$, which is about $51 \%$ lower than that of the untreated samples. Similar results have been found on laser treated Ti-6Al-4V alloy that the contact angle measured perpendicular to the orientation of the grooves was very different from that parallel to the grooves $[22,23]$.

\section{Surface chemical composition}

Fig. 3 shows the XPS spectra of the untreated and lasertreated TZNT surface. It can be seen that apart from the presence of the expected key elements ( $\mathrm{Ti}, \mathrm{Zr}, \mathrm{Nb}, \mathrm{Ta}$ and $\mathrm{O})$, both laser-treated and untreated surfaces reveal the presence of carbon (C). It was believed that carbon was present as a contamination from environment or cleaning process [24]. A summary of different elements detected in the outmost oxide layers on the laser-treated and untreated surfaces is given in Table 1. The quantitative compositional results indicate that the oxide film is enriched with more non-metallic elements $(\mathrm{O}$ and $\mathrm{C})$ after laser surface treatment. The relative concentration of non-metallic elements in the outermost surface layer increases. In addition, the higher $\mathrm{O}$ concentration of untreated samples is owing to the electrobrightening which can form an oxide layer on the surface.

Fig. 4 shows the XPS spectra of different elements obtained from narrow scans over the $\mathrm{Ti} 2 \mathrm{p}, \mathrm{Nb} 3 \mathrm{~d}, \mathrm{Zr} 3 \mathrm{~d}$, and $\mathrm{Ta} 4 \mathrm{f}$ lines for the laser-treated and untreated TNZT samples. The Ti 2p XPS spectra (Fig. 4a) of the untreated surface shows that the outermost oxide layer is mainly composed of $\mathrm{TiO}_{2}\left(\right.$ or $\mathrm{Ti}^{4+}$ ), and small amounts of metallic $\mathrm{Ti}$ is also found. However, the laser-treated surface contains only $\mathrm{TiO}_{2}$ without metallic Ti. The $\mathrm{Zr} 3 \mathrm{~d}$ XPS spectrum (Fig. $4 \mathrm{~b}$ ) of the untreated surface shows that outermost oxide layer contains the $\mathrm{Zr}^{4+}$ and some metallic $\mathrm{Zr}$. In comparison, the outermost oxide layer on the lasertreated surface is composed of $\mathrm{Zr}^{4+}$ and fewer metallic $\mathrm{Zr}$. For $\mathrm{Nb}$ in the surface as seen in Fig. $4 \mathrm{c}$, it is noted that $\mathrm{Nb}^{5+}$ peaks exist in both of the sample before and after leaser treatment, while the peak of $5 / 2 \mathrm{Nb}^{0}$ almost disappears after laser treatment. Ta oxide is characterized by $\mathrm{Ta}^{5+}$ peaks in the sample, which is independent to the laser treatment. These results indicated that the leaser treatment promoted the oxidation of $\mathrm{Ti}, \mathrm{Zr}$ and $\mathrm{Nb}$ on the surface of the TZNT alloy, although high purity argon was used to protect the surface of the sample. Similar result has been found in Chan's study that a complete $\mathrm{Nb}$ oxide was found in the outermost layer on the lasertreated Ti-35.3Nb-7.3Zr-5.7Ta alloy and no other suboxides were detected [24].

\section{Corrosion properties}

Fig. 5a demonstrates the open circuit potential curves of the untreated and laser-treated TZNT samples in Hank's solution at $37^{\circ} \mathrm{C}$. The steady values of OCPs of the samples are listed in Table 2. An obvious result can be obtained from Fig. 5a that the OCP of laser-treated TZNT

Table 1 The element content on TZNT surface with and without laser ablation

\begin{tabular}{ccccccc}
\hline Element & $\mathrm{O}$ & $\mathrm{Ti}$ & $\mathrm{Zr}$ & $\mathrm{Nb}$ & $\mathrm{C}$ & \\
\hline Untreated (at.\%) & 38.47 & 6.21 & 3.70 & 1.69 & & \\
Laser-treated (at.\%) & 35.56 & 4.80 & 2.90 & 1.11 & 0.69 & 55.22 \\
\hline
\end{tabular}



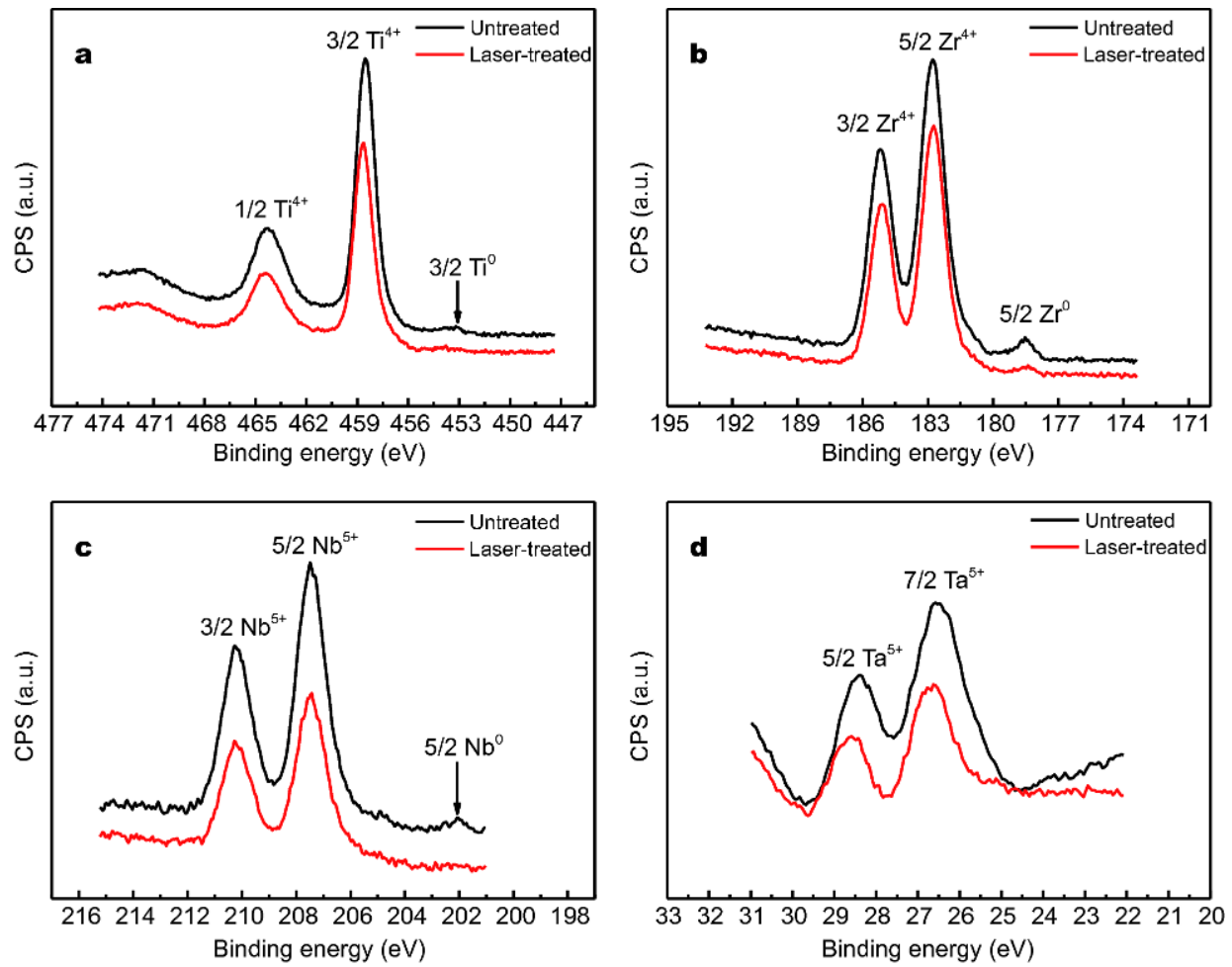

Figure 4 The XPS narrow spectra of (a) Ti, (b) Zr, (c) $\mathrm{Nb}$ and (d) $\mathrm{Ta}$ on the surface of untreated and laser-treated sample.
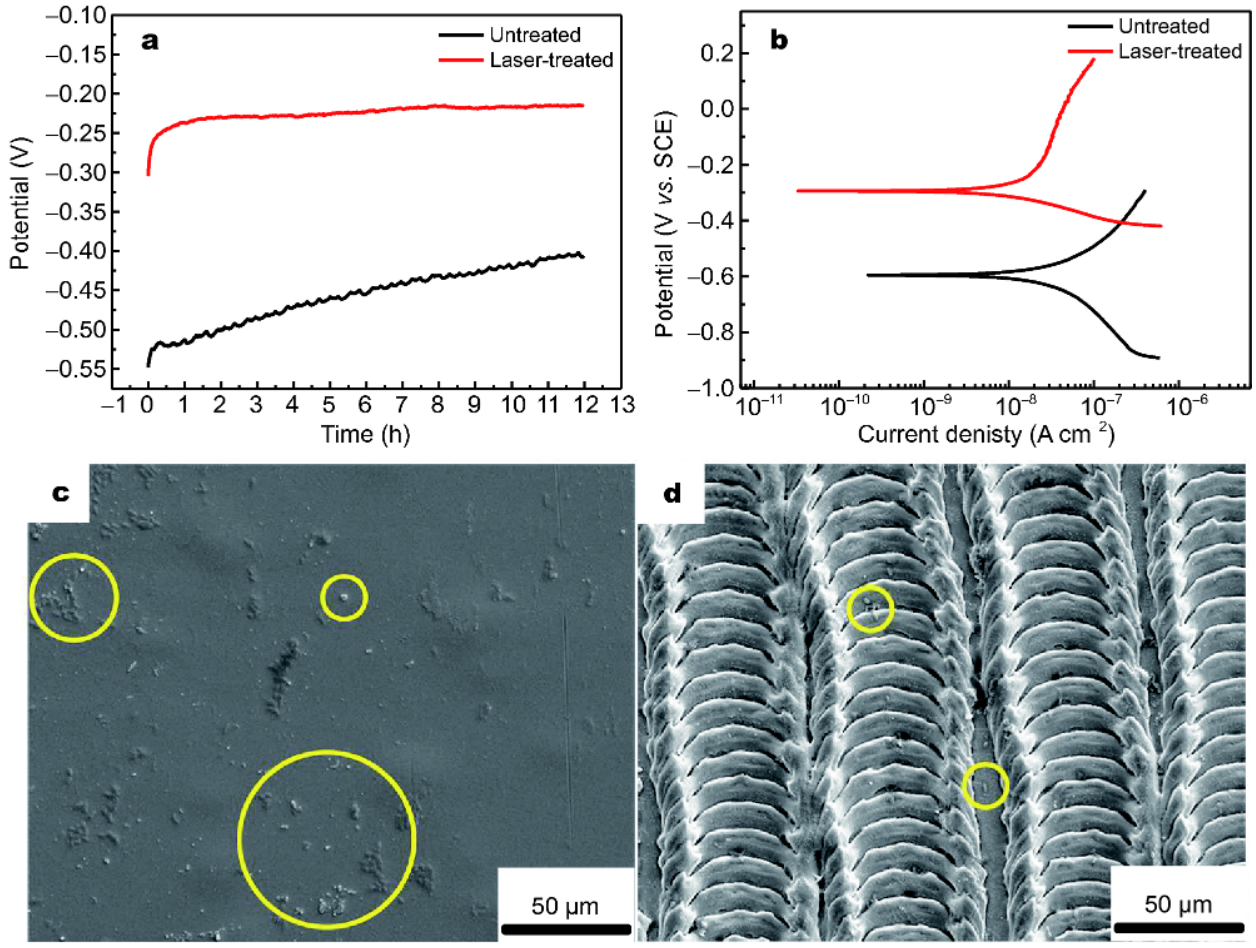

Figure 5 The open circuit potential curves (a) and the potentio-dynamic polarization curves (b) of untreated and laser-treated TZNT samples in Hank's at $37^{\circ} \mathrm{C}$. (c, d) The SEM images of untreated and laser-treated samples after potentio-dynamic polarization test in Hank's at $37^{\circ} \mathrm{C}$. The regions marked by yellow circle contain the corrosion products. 
Table 2 The open circuit potentials (OCP), corrosion potentials $\left(E_{\text {corr }}\right)$, corrosion current densities $\left(i_{\text {corr }}\right)$ and polarization resistance $\left(R_{\mathrm{p}}\right)$ of untreated and laser-treated samples in Hank's at $37^{\circ} \mathrm{C}$

\begin{tabular}{ccccc}
\hline Sample & OCP $(\mathrm{mV})$ & $E_{\text {corr }}(\mathrm{mV})$ & $i_{\text {corr }}\left(\mathrm{A} \mathrm{cm}^{-2}\right)$ & $R_{\mathrm{p}}\left(\Omega \mathrm{cm}^{2}\right)$ \\
\hline Untreated & -405.68 & -609.85 & $3.70 \times 10^{-8}$ & $1.20 \times 10^{6}$ \\
Laser-treated & -214.82 & -304.55 & $1.04 \times 10^{-8}$ & $2.26 \times 10^{6}$ \\
\hline
\end{tabular}

is much higher than that of the untreated TZNT. A higher OCP indicates the formation of a thicker passivation layer $[25,26]$. The higher OCP of laser-treated TZNT indicates that laser-treated TZNT sample surface is more chemically stable compared to untreated TZNT. XPS analysis results can interpretate the changes of curves from Fig. $5 \mathrm{a}$ that the surfaces of untreated samples contain more metallic $\mathrm{Ti}, \mathrm{Zr}$ and $\mathrm{Nb}$ compared with lasertreated samples.

Fig. $5 \mathrm{~b}$ displays the potentio-dynamic polarization curves of the untreated and laser-treated TZNT samples in Hank's solution at $37^{\circ} \mathrm{C}$. Fig. $5 \mathrm{c}$, d show the surface morphology images of the untreated and laser-treated TZNT samples after potentio-dynamic polarization test in Hank's solution at $37^{\circ} \mathrm{C}$. Table 3 shows the corrosion potential $\left(E_{\text {corr }}\right)$ and corrosion current density $\left(i_{\text {corr }}\right)$ of the TZNT in this work and those of laser treated Ti-6Al-4V [27] and Ti-35.3Nb-7.3Zr-5.7Ta [24] alloys. It is seen that the $E_{\text {corr }}$ of the laser-treated TZNT samples increases by more than $300 \mathrm{mV}$. The $i_{\text {corr }}$ of the laser-treated TZNT samples is obvious lower than that of the untreated sample regardless of the increased surface area of lasertreated samples. The corrosion products of untreated samples are significantly more than that of laser-treated samples. These results reveal a significant improvement in corrosion resistance of TZNT alloy after laser ablation. According to the XPS analysis, it is found that the laser treatment promoted the surface oxidation of TZNT alloy. Therefore, it is believed that the improved corrosion resistance measured in the polarization tests is due to the formation of more protective oxide film on the metal surface after laser ablation. Similar results have been found in Ti-6Al-4V [27] and Ti-35.3Nb-7.3Zr-5.7Ta [24] alloys. The increase in corrosion potential of laser-treated $\mathrm{Ti}-6 \mathrm{Al}-4 \mathrm{~V}$ was possibly due to the presence of oxide as well as formation of refined microstructure and microstructural homogenization [27]. The laser-formed $\mathrm{TiO}_{2} /$ $\mathrm{Nb}_{2} \mathrm{O}_{5}$ layer on the surface of Ti-35.3Nb-7.3Zr-5.7Ta was contributed to the improved corrosion resistance of the alloy [24].

\section{Cellular attachment and proliferation}

Fig. 6 shows the MTT assay of MC3T3-E1 cells attached on the TZNT for 12, 24 and $72 \mathrm{~h}$ culture. It is seen that the cell number increases with increasing culture time for both of the samples. The cell number of laser-treated sample is slightly higher than that of the untreated samples at 12 or $24 \mathrm{~h}$ culture time. Therefore, the lasertreated TZNT alloy shows a positive effect on cell proliferation. Liang et al. [28] created several grooved morphologies on NiTi alloy surface by a femtosecond laser and the cell proliferation rate was found increasing with the increasing culture time due to the modification of the surface oxide with the reduction of $\mathrm{Ni}$ content. In addition, it was reported that the formation of a stable $\mathrm{TiO}_{2}$ layer on a $\mathrm{Ti}$ substrate through anodic oxidation suppressed the adsorption of surface contaminants, leading to an improved surface hydrophilicity and enhanced cellular adhesiveness [29]. No significant differences in cell proliferation are found between the lasertreated and untreated samples after $72 \mathrm{~h}$ culture.

Fig. 7 shows the morphology of MC3T3-E1 cells on the untreated and laser-treated samples after 12, 24 and $72 \mathrm{~h}$ culture. It can be seen that the cells grew up, spread, contacted and fused gradually with increasing culture time for both of the untreated samples and laser-treated samples. It is seen in Fig. 7a that the MC3T3-E1 cells on the untreated samples exhibited oval and fusiform morphologies after $12 \mathrm{~h}$ culture. The filopodia of cells adhered to the surface of samples irregularly. It can be

Table 3 The corrosion potentials $\left(E_{\text {corr }}\right)$ and corrosion current densities $\left(i_{\text {corr }}\right)$ of Ti-20Zr-10Nb-4Ta, Ti-6Al-4V and Ti-35.3Nb-7.3Zr-5.7Ta alloys

\begin{tabular}{cccc}
\hline Alloy composition & Sample & $E_{\text {corr }}(\mathrm{mV})$ & $i_{\text {corr }}\left(\mathrm{A} \mathrm{cm}^{-2}\right)$ \\
\hline Ti-20Zr-10Nb-4Ta & Untreated & -609.85 & $3.70 \times 10^{-8}$ \\
& Treated & -304.55 & $1.04 \times 10^{-8}$ \\
Ti-6Al-4V [27] & Untreated & -614 & $/$ \\
& Treated & -335 & $/$ \\
Ti-35.3Nb-7.3Zr-5.7Ta [24] & Untreated & -590 & 0.01507 \\
& Treated & -431 & 0.00028 \\
\hline
\end{tabular}




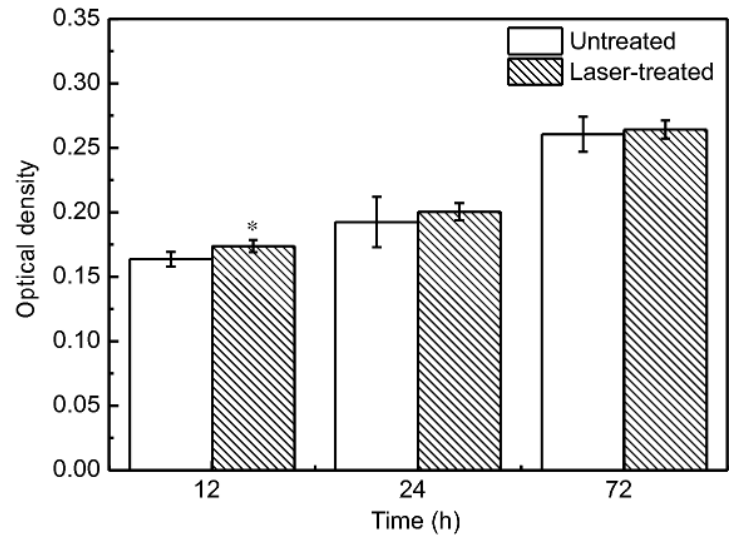

Figure 6 The MTT assay of MC3T3-E1 cells cultured for 12, 24 and $72 \mathrm{~h}$ on the untreated and laser-treated TZNT alloys. (* indicates significant difference compared with untreated TZNT $(p<0.05)$.)
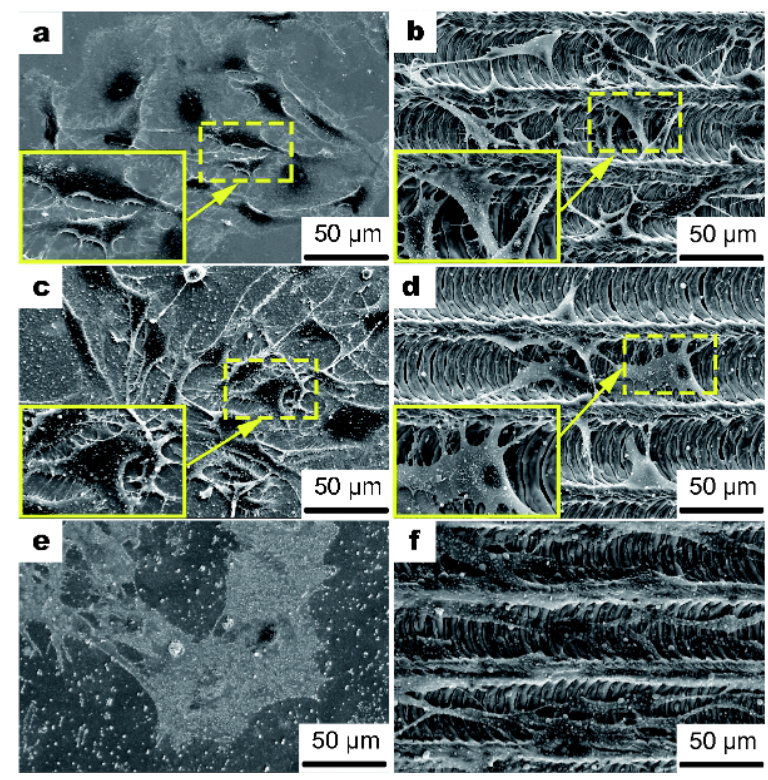

Figure 7 The SEM images of MC3T3-E1 cells cultured on the untreated TZNT alloys for 12 (a), 24 (c) and $72 \mathrm{~h}$ (e), and on the laser-treated TZNT alloys for 12 (b), 24 (d) and $72 \mathrm{~h}$ (f). The regions enclosed by yellow line represent the high magnification image.

seen in Fig. 7b that the most of the cells on laser-treated samples after $12 \mathrm{~h}$ culture displayed triangular shape with filopodia attached on the ridge of grooves. The phenomenon can be observed explicitly in the high magnification image identified with a yellow imaginary line. For the untreated sample after $24 \mathrm{~h}$ culture as show in Fig. 7c, the cells grew up in size, and the filopodia of cells begun bonding each other. Moreover, cells on the laser treated sample after $24 \mathrm{~h}$ culture produced more filopodia attached on the ridge (see Fig. $7 \mathrm{~d}$ ). When the culture time reached $72 \mathrm{~h}$, it is observed in Fig. $7 \mathrm{e}$ that the cells on the untreated sample were completely fused and grew laminated. These results indicated that more and more connections between filopodia of cells occurred with the increasing incubation time. It can be observed in Fig. $7 \mathrm{f}$ that most of the cells on the laser treated sample after $72 \mathrm{~h}$ culture exhibit shuttle-like shape distributed along the groove direction. This indicates that the growth of attached MC3T3-E1 cells was definitely guided by the anisotropic groove morphology as well as the reduction of water contact angle along the groove direction. Similar results have been found on a laser treated $\mathrm{Ti}-6 \mathrm{Al}-4 \mathrm{~V}$ surfaces, on which the direction of microgrooves and nanostructures controlled the cell alignment regularly, and the cells grew along the groove primarily [30]. Based on the results of cell culture experiments, it can be concluded that laser ablation improved the surface biocompatibility because of the formation of more stable oxide layer and improved corrosion resistance. Moreover, the micro-grooves not only guide the cell growth, but also provide more surface area in comparison to the untreated surfaces, which was favorable for protein adsorption, resulting in improved biocompatibility $[22,28]$.

\section{CONCLUSIONS}

The corrosion behavior and cytocompatibility of $\mathrm{Ti}-$ $20 \mathrm{Zr}-10 \mathrm{Nb}-4 \mathrm{Ta}$ alloy have been investigated and the following conclusions were reached. The laser treatment caused rougher groove morphologies on the surface of the $\mathrm{Ti}-20 \mathrm{Zr}-10 \mathrm{Nb}-4 \mathrm{Ta}$ alloy and promoted the oxidation of $\mathrm{Ti}, \mathrm{Zr}$ and $\mathrm{Nb}$ elements. The corrosion resistance of the alloy was improved by laser treatment as evidenced by an enhanced corrosion potential from -609.85 to -304.55 $\mathrm{mV}$ and a reduced corrosion current density from $3.70 \times 10^{-8}$ to $1.04 \times 10^{-8} \mathrm{~A} \mathrm{~cm}^{-2}$ in the anodic polarization test in Hank's solution. The laser-treated Ti-20Zr-10Nb4Ta alloy showed similar cell viability compared with the untreated alloy. Moreover, more hydrophilic surface and presence of the anisotropic groove pattern induced obvious orientation for cell growth.

\section{Received 5 November 2017; accepted 5 March 2018; published online 21 March 2018}

1 Deligianni D. Effect of surface roughness of the titanium alloy Ti$6 \mathrm{Al}-4 \mathrm{~V}$ on human bone marrow cell response and on protein adsorption. Biomaterials, 2001, 22: 1241-1251

2 Scarano A, Piattelli M, Caputi S, et al. Bacterial adhesion on commercially pure titanium and zirconium oxide disks: an in vivo human study. J Periodontol, 2004, 75: 292-296

3 El-Ghannam A, Starr L, Jones J. Laminin-5 coating enhances epithelial cell attachment, spreading, and hemidesmosome as- 
sembly on Ti-6Al-4V implant material in vitro. J Biomed Mater Res, 1998, 41: 30-40

4 Niinomi M, Nakai M, Hieda J. Development of new metallic alloys for biomedical applications. Acta Biomater, 2012, 8: 3888-3903

5 Hao YL, Li SJ, Yang R. Biomedical titanium alloys and their additive manufacturing. Rare Met, 2016, 35: 661-671

6 Qu WT, Sun XG, Yuan BF, et al. Tribological behaviour of biomedical Ti-Zr-based shape memory alloys. Rare Met, 2017, 36: 478-484

7 Jin $\mathrm{M}$, Lu X, Qiao Y, et al. Fabrication and characterization of anodic oxide nanotubes on TiNb alloys. Rare Met, 2016, 35: 140148

8 Oliveira NTC, Ferreira EA, Duarte LT, et al. Corrosion resistance of anodic oxides on the $\mathrm{Ti}-50 \mathrm{Zr}$ and $\mathrm{Ti}-13 \mathrm{Nb}-13 \mathrm{Zr}$ alloys. Electrochim Acta, 2006, 51: 2068-2075

9 Elias LM, Schneider SG, Schneider S, et al. Microstructural and mechanical characterization of biomedical $\mathrm{Ti}-\mathrm{Nb}-\mathrm{Zr}(-\mathrm{Ta})$ alloys. Mater Sci Eng-A, 2006, 432: 108-112

10 Fukuda A, Takemoto M, Saito T, et al. Bone bonding bioactivity of $\mathrm{Ti}$ metal and $\mathrm{Ti}-\mathrm{Zr}-\mathrm{Nb}-\mathrm{Ta}$ alloys with $\mathrm{Ca}$ ions incorporated on their surfaces by simple chemical and heat treatments. Acta Biomater, 2011, 7: 1379-1386

11 Ozan S, Lin J, Li Y, et al. New Ti-Ta-Zr-Nb alloys with ultrahigh strength for potential orthopedic implant applications. J Mech Behav BioMed Mater, 2017, 75: 119-127

12 Xue P, Li Y, Li K, et al. Superelasticity, corrosion resistance and biocompatibility of the Ti-19Zr-10Nb-1Fe alloy. Mater Sci Eng-C, 2015, 50: 179-186

13 Xiong C, Xue P, Sun B, et al. Effect of annealing temperature on the microstructure and superelasticity of Ti-19Zr-10Nb-1Fe alloy. Mater Sci Eng-A, 2017, 688: 464-469

14 Xiong C, Yao L, Yuan B, et al. Strain induced martensite stabilization and shape memory effect of $\mathrm{Ti}-20 \mathrm{Zr}-10 \mathrm{Nb}-4 \mathrm{Ta}$ alloy. Mater Sci Eng-A, 2016, 658: 28-32

15 Soboyejo WO, Nemetski B, Allameh S, et al. Interactions between MC3T3-E1 cells and textured Ti6Al4V surfaces. J Biomed Mater Res, 2002, 62: 56-72

16 Ohtsu N, Kozuka T, Yamane M, et al. Surface chemistry and osteoblast-like cell response on a titanium surface modified by a focused Nd:YAG laser. Surf Coatings Tech, 2017, 309: 220-226

17 Man HC, Cui ZD, Yue TM. Corrosion properties of laser surface melted NiTi shape memory alloy. Scripta Mater, 2001, 45: 14471453

18 Wong MH, Cheng FT, Pang GKH, et al. Characterization of oxide film formed on NiTi by laser oxidation. Mater Sci Eng-A, 2007, 448: 97-103

19 Lawrence J, Hao L, Chew HR. On the correlation between Nd:YAG laser-induced wettability characteristics modification and osteoblast cell bioactivity on a titanium alloy. Surf Coatings Tech, 2006,
200: 5581-5589

20 Chen J, Ulerich JP, Abelev E, et al. An investigation of the initial attachment and orientation of osteoblast-like cells on laser grooved Ti-6Al-4V surfaces. Mater Sci Eng-C, 2009, 29: 1442-1452

21 Ulerich JP, Ionescu LC, Chen J, et al. Modifications of Ti-6Al-4V surfaces by direct-write laser machining of linear grooves. Proc of SPIE, 2007, 6458: 645819

22 Mukherjee S, Dhara S, Saha P. Enhancing the biocompatibility of Ti6Al4V implants by laser surface microtexturing: an in vitro study. Int J Adv Manuf Technol, 2015, 76: 5-15

23 Raimbault $\mathrm{O}$, Benayoun S, Anselme K, et al. The effects of femtosecond laser-textured $\mathrm{Ti}-6 \mathrm{Al}-4 \mathrm{~V}$ on wettability and cell response. Mater Sci Eng-C, 2016, 69: 311-320

24 Chan CW, Lee S, Smith G, et al. Enhancement of wear and corrosion resistance of beta titanium alloy by laser gas alloying with nitrogen. Appl Surf Sci, 2016, 367: 80-90

25 Saebnoori E, Shahrabi T, Sanjabi S, et al. Surface characteristics and electrochemical behaviour of sputter-deposited NiTi thin film. Philos Mag, 2015, 95: 1696-1716

26 Li K, Li Y, Huang X, et al. Surface microstructures and corrosion resistance of Ni-Ti-Nb shape memory thin films. Appl Surf Sci, 2017, 414: 63-67

27 Kumari R, Scharnweber T, Pfleging W, et al. Laser surface textured titanium alloy (Ti-6Al-4V) - Part II - Studies on bio-compatibility. Appl Surf Sci, 2015, 357: 750-758

28 Liang C, Wang H, Yang J, et al. Biocompatibility of the micropatterned NiTi surface produced by femtosecond laser. Appl Surf Sci, 2012, 261: 337-342

29 Ohtsu N, Kozuka T, Hirano M, et al. Electrolyte effects on the surface chemistry and cellular response of anodized titanium. Appl Surf Sci, 2015, 349: 911-915

30 Dumas V, Rattner A, Vico L, et al. Multiscale grooved titanium processed with femtosecond laser influences mesenchymal stem cell morphology, adhesion, and matrix organization. J Biomed Mater Res, 2012, 100A: 3108-3116

Acknowledgements This work was supported by the National Natural Science Foundation of China (NSFC, 51771011) and the Fundamental Research Funds for the Central Universities (KG12002601).

Author contributions Xue X conceived and designed the experiments, analyzed the results, and wrote the manuscript. Ma $\mathrm{C}$ prepared the samples and participated in the characterization; An $\mathrm{H}$ involved in the paper writing and experiments designing; Li Y and Guan Y supervised the experiments designing and paper writing. All authors contributed to the general discussion.

Conflict of interest The authors declare that they have no conflict of interest. 


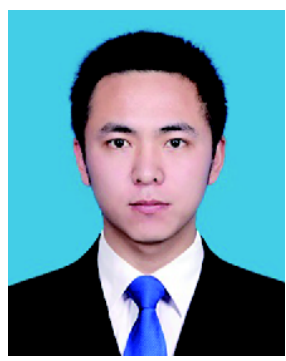

Xianda Xue received his bachelor's degree from Beihang University in 2014. Now he is pursuing his PhD degree (metallic materials) at Beihang University continuously. His research interests focus on the technique improving surface of metallic materials.

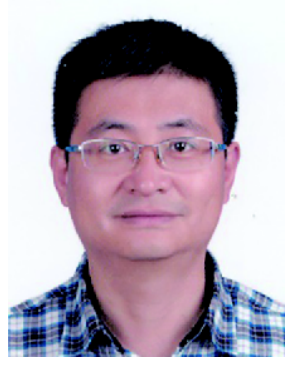

Yan Li is a professor of the School of Materials Science and Engineering at Beihang University. He received his $\mathrm{PhD}$ degree from Dalian University of Technology in 2001. His current research interests include shape memory materials, biomedical materials, and supercapacitors and battery materials.

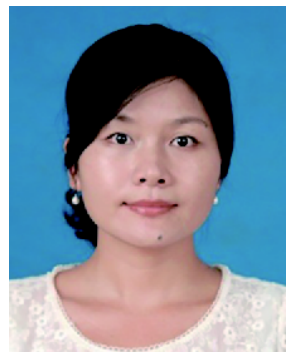

Yingchun Guan is currently a professor in the School of Mechanical Engineering and Automation, Beihang University. She received her PhD degree from Nanyang Technological University (Singapore) in 2011. She had been served as Scientist in Singapore Institute of Manufacturing Technology from 2011 to 2014. Her major research interests include laser precision manufacturing and laser additive manufacturing.

\section{激光表面改性Ti-20Zr-10Nb-4Ta合金的耐腐蚀性与细胞相容性研究}

薛贤达 ${ }^{1}$, 马程鹏 ${ }^{2}$, 安红娟 ${ }^{1}$, 李岩 ${ }^{1,3^{*}}$, 管迎春 ${ }^{2,4,5^{*}}$

摘要 本文系统研究了激光表面改性对Ti-20Zr-10Nb-4Ta(TZNT)合金耐腐蚀性和细胞相容性的影响. 扫描电镜观察结果表明, 激光改性 能够在TZNT合金表面制造沟槽结构, 沟槽宽度大概 $40 \mu \mathrm{m}$, 沟槽深度大概 $10 \mu \mathrm{m}$. 与未处理样品相比, 改性样品表面沿沟槽方向的水接触角 减小了 $51 \%$. 激光处理过程使样品表面金属态的 $\mathrm{Ti} 、 \mathrm{Zr}$ 和 Nb转变成了稳定的氧化态. 在 $37^{\circ} \mathrm{C}$ 的 Hank's溶液中进行动电位极化测试发现, 改 性样品的自腐蚀电位升高了 $50 \%$, 自腐蚀电流密度下降了 $72 \%$, 说明激光改性能够提高TZNT合金的而腐蚀能力. MTT实验结果表明小鼠成 骨细胞(MC3T3-E1)在改性样品和非改性样品表面具有相似的细胞活性. 从细胞形貌可以看出, 细胞出现了沿沟槽方向生长的导向性. 综 上所述, 新型生物医用TZNT合金有望成为骨科和牙科植入领域的替代材料. 